\title{
EMPOWERING OTHERS IN SALESTEAM KNOWLEDGE CONVERSION: A STRATEGY TO BOOST SELLING PERFORMANCE
}

\author{
Ken Sudarti \\ Dept. of Management, Faculty of Economics, Universitas Islam Sultan Agung, Semarang, Central Java, Indonesia, \\ kensudarti@unissula.ac.id
}

\begin{abstract}
This study aims to examine the role of empowering others on knowledge conversion in improving selling performance. Empowering others on knowledge conversion is the spirit of salesmen who are members of a sales team to ask and help colleagues to be willing and able to do the best knowledge conversion activities. This study used 193 sharia insurance salespeople as respondents in Indonesia. The regression model is used to analyze the data and test the empirical model. Empowering others on knowledge conversion has proven to improve the selling performance of sharia insurance salespeople in Indonesia. The concept of empowering others on knowledge conversion is a critical reconstruction of needs for achievement theory and social capital theory through the internalization of Islamic values. Through empowering others in doing knowledge conversion, salespeople who are members of the sales team will have updated sales knowledge to achieve the best performance.
\end{abstract}

Keywords: empowering others on knowledge conversion, SECI process, selling performance

Received Revised Accepted Published

August 26, $2021 \quad$ September 11, $2021 \quad$ September 14, $2021 \quad$ September 30, 2021

To cite this article: Sudarti, K. (2021). Empowering others in salesteam knowledge conversion: a strategy to boost selling performance. IJIBE (International Journal of Islamic Business Ethics), 6 (2), 135-147. http://dx.doi.org/10.30659/ijibe.6.2.135-147

\section{INTRODUCTION}

One of the knowledge management practices and policies is knowledge creation which has been recognized as playing an essential role in the organizational success (Nonaka et al., 1994). The knowledge creation process that is done well will produce new knowledge by incorporating various sources of personal knowledge (Lee \& Choi, 2003). The knowledge created includes tacit and explicit knowledge. Knowledge creation is necessary because knowledge obtained from various sources needs to be converted into organizational knowledge for the more comprehensive benefit and business success. Knowledge is created continuously through dynamic interactions between tacit and explicit knowledge. This type of interaction is called knowledge conversion, which includes 4 (four) stages that are connected cyclically and spirally, starting from Socialization, Externalization, Combination, and Internalization (Nonaka et al., 1994)(Khodakarami \& Chan, 2014).

Although knowledge conversion has been widely used in various organizations, it is still infrequent to identify the desire of individuals to empower their co-workers through activities to ask and help their co-workers be willing and able to be involved in the knowledge conversion process. Voluntary behavior can be classified into intrinsic motivation. So far, very few studies correlated knowledge creation with intrinsic motivation, especially 
motivation associated with religious values, especially Islam. (Swift et al., 2010) states that when an individual has a superior performance orientation, he is more willing to help.

Islam teaches its followers to carry out all activities based on worship and only expect the pleasure of Allah. Therefore, the motivation to empower colleagues in the knowledge creation process must also be based on the intention to activate the idle capacity of their colleagues so that they can perform optimally. Allah says in Holy Qur'an 103:2-3 that "Indeed, humans are in a state of loss, except for those who believe and do good and advise one another to truth and patience."

This is very different from the statement of (Polley \& Ribbens, 1998), that individuals who want to achieve the highest results only focus on themselves in most cases. This means that there is no spirit of the congregation between individuals, caring for each other, asking, and helping each other. The spirit of togetherness relates to the relationship between team members. This relational relationship will create a cooperative norm, namely the willingness to respect differences, openness to the thoughts of others, the expectation of reciprocity and cooperation ( $\mathrm{Yu}$ et al., 2013). The enthusiasm to empower co-workers is very likely to improve performance through taking and giving new knowledge. This statement is supported by the Word of God in the Holy Qur'an that "Together (united) is love (grace) and division is torment" (Holy Qur'an: Ali Imron: 102-103). So, Allah SWT confirms and instructs people of faith and piety to hold fast to the ropes of Allah's religion and live in the congregation and strictly forbids firqah (divorce).

Based on the limitations of previous studies, this study tries to offer a new concept, namely empowering others on knowledge conversion, which is defined as the spirit of individuals who are members of a team to ask and help their colleagues to be willing and able to do the best knowledge conversion activities. This concept is an internalization of Islamic values in intrinsic motivation, especially related to the knowledge conversion process. Sharia Insurance Company was chosen as the object to test the research model. Salespeople who are members of a sales team are used as respondents for this study. These salespeople play a vital role in improving service marketing performance because they are representatives of the organization who meet directly with consumers.

This concept is very different from the existing concept of motivation because it has touched the dimension of the afterlife. Individuals have the spirit to empower others in doing knowledge conversion based on sincerity and get merit. They are aware that humans are social creatures and cannot live alone, so they must care about them. Through this concern, more and more knowledge can be converted. If each team member has the spirit to empower his co-workers mutually, then da'wah (preaching) and helping behavior will become a team culture that ultimately impacts the selling performance of sharia insurance salespeople.

\section{Conceptual Mapping Empowering Others on Knowledge Conversion (EOonKC).}

Empowering others on knowledge conversion (EOonKC) is a new concept resulting from the synthesis of Islamic values, the need for achievement theory, and relational social capital theory. Empowering others on knowledge conversion is the spirit of salesmen who are members of a sales team to ask and help colleagues to be willing and able to do the best knowledge conversion activities by making themselves as the role models at first in doing the best knowledge conversion activities. The spirit of asking and helping to carry out knowledge 
conversion is derived from social capital theory combined with Islamic values, while the spirit of conducting knowledge conversion in the best way is derived from the need for achievement theory combined with Islamic values.

The new concept of EOonKC uses Islamic values as the main foundation. Salesmen who obey their religion will do all activities based on worship (Zahrah, Norasyikin, Hamid, Huda, \& Rani, 2016). Salesmen with high EOonKC will care about the achievements of their colleagues. They realize that they are working in a team with the ability to do different knowledge conversions, strengthen their desire to do preaching ( $\left.d a^{\prime} w a h\right)$, and ask their colleagues to optimize their resources. This spirit arises because of relational capital. The spirit of togetherness that exists between team members raises the willingness to accept critical thinking, the hope of reciprocity, and cooperation (Yu, Hao, Dong, \& Khalifa, 2013). This behavior is in accordance with Islamic values as outlined in (Holy Qur'an;103: 2-3) that "indeed man is in a state of loss, except for those who believe and work on virtue and advise one another for truth and patience".

Efforts to spread kindness are conveyed with patience and compassion (Holy Qur'an, Al-Balad verses 17-18); (Holy Qur'an, Al-'Asr verses 1-3) as well as with good communication language. Choosing the correct language will make communication more effective. (Yen et al., 2011) concluded that the trust between two parties who communicate with each other is influenced by effective communication. If coworkers experience difficulties, individuals with high spirit of EOonKC are willing to help without being asked. Individual willingness to do work that is not a responsibility is strongly influenced by the level of religiosity (Olowookere \& Adekeye, 2016). These individuals have a solid commitment to the success of the organization.

Individuals with the spirit of EOonKC are enthusiastic about making themselves role models before asking their co-workers to do knowledge conversion activities. This is very important because the personality of the messenger will affect the perception and evaluation of the information conveyed ( $\mathrm{Wu}, 2007)$. Professionalism is used to measure knowledge conversion activities because he believes that Allah SWT sees everything he does. They do not hesitate to form partnerships with co-workers as part of maximizing efforts to spread the best knowledge. The performance will increase with collaboration (Chen et al., 2014). As the Prophet Muhammad said, hard work absolves human sins; besides, the best food a person eats is what he eats from his work. Allah says: "And each person has a level according to what they do" (Holy Qur'an 6:132). "And man, only gains what he has fought for" (Holy Qur'an 53:39).

In addition, the spirit of doing EOonKC continues to be maintained by always being eager to do long-life learning. This arises because the salesman believes that Allah will not change the condition of a people if the people do not try to change what is in themselves (Holy Qur'an, Ar-Ra'd verse 11). Continuous improvement is made by making small, rather radical changes (Elias \& Davis, 2018). Individuals with a high learning orientation will open themselves to new knowledge, are willing to interact with the external environment to gain new knowledge, and dare to take risks. Something new can be done if the individual has a learning orientation (Calisir et al., 2013).Hence, in the context of empowering others on knowledge conversion, salesmen have a high enthusiasm to share knowledge with colleagues about how to do the best sales activity. They improved the method of socialization 
continuously so that his coworkers understood what he was saying. Invitations to disseminate knowledge were conveyed to colleagues to be more active in sharing knowledge. Help is ready for colleagues who have not been able to communicate their best knowledge. A similar process is carried out by the salesman for the next steps of knowledge conversion, which are externalization, combination and internalization.

This process is what distinguishes between the new concept of empowering others on knowledge conversion and the SECI process by Nonaka (1994), that not only individuals are active in the process of creating knowledge, but there are also efforts to empower others so that they are willing and able to engage and convert knowledge. Through empowering others on knowledge socialization, the idle knowledge that is in the minds of each salesman will be explored more deeply so that the new knowledge will be more complete and quality.

\section{Hypothesis Development}

In the SECI process, the socialization stage is a crucial initial stage. (Mosala- et al., 2016) stated that among the many processes of the knowledge management cycle, the socialization stage was identified as the most critical process and the foundation for effective knowledge management.

Socialization is a process of changing tacit knowledge. Tacit knowledge is inherent in individuals, one of which is obtained from experience (Göksel \& Aydıntan, 2017). Through the socialization process, individual tacit knowledge is shared with other individuals so that each individual's tacit knowledge is more complete, which ultimately impacts the enrichment of organizational knowledge (Nonaka et al., 1994). Various activities such as brainstorming, discussion, observation, monitoring, and informal meetings can be a medium for sharing tacit knowledge.

The socialization process can be interpreted as part of knowledge sharing, especially tacit knowledge sharing (Sabherwal \& Becerra-Fernandez, 2003). Knowledge sharing is the primary means of facilitating the flow of knowledge (Lawson et al., 2009). Sharing is defined as the process of taking and giving knowledge because it involves two or more parties, namely those who share and those who provide new knowledge. Therefore, this process will be more effective when carried out in a team where each member has the motivation to strengthen team members and believe in a significant positive impact with the dissemination of the new knowledge. All of this is under Islamic values. (Behaviors et al., 2014) stated that Islamic values had encouraged Muslims to share knowledge which is expected to contribute to the welfare of society on a broader scale, including in the workplace.

Voluntary helping and asking others on Socialization is the spirit of individuals to help their coworkers in changing their tacit knowledge by giving and receiving new knowledge from coworkers. Individuals who have the sincerity to give and receive tacit knowledge will be actively involved in every informal discussion. Organ (2006) states that helping behavior can improve team performance through team morale.

In the context of a sales team, a salesman who realizes that the success of market expansion is determined by the accumulation of skills of all team members, then he will volunteer to help his team to enrich his sales knowledge by always asking colleagues to be involved in discussing the latest sales methods through informal meetings. This individual does not hesitate to provide valuable experience because of the principle of fair partnership 
that he believes in. In other words, in the context of knowledge dissemination, a salesperson will volunteer to help create new knowledge through the conversion process.

H1: The stronger the voluntary asking and helping spirit in doing knowledge dissemination, the higher the selling performance

The second SECI process is Externalization. In the process of Externalization, individuals are willing to take pictures, diagrams, and illustrations whose purpose is to clarify the process of articulating tacit knowledge hidden in their minds so that they are easier to understand. If this activity is applied to salespeople, it can be said that salespeople who have the sincerity to ask and help their colleagues in the knowledge externalization process will do their best to illustrate their knowledge and sales experience in the form of videos or flowcharts. His sincerity is based on a belief that work is worship. According to (Pfeffer \& Veiga, 2009) and (Karakas, 2010), spiritual belief is one of performance triggers.

A salesman who has a strong religious foundation understands that when he masters a unique knowledge of how to increase sales, he wants his co-workers to also have the same knowledge by taking and giving knowledge that is easy to learn. Employees involved in altruistic behavior have tremendous potential for progress, value recommendations, and are considered to be more emotionally stable, open, pleasant, and conscientious (Rosopa et al., 2013).

H2: The stronger the voluntary asking and helping spirit in externalizing knowledge, the higher the selling performance.

The third SECI process is Combination, which converts explicit knowledge into new knowledge that is completer and more complex through integration and dissemination at the organizational level. This process is facilitated by the database and network using computerbased communication through sorting, adding, combining, and categorizing with the support of a computer-based database (Nonaka \& von Krogh, 2009).Voluntary helping and asking others on Combination is the spirit of individuals to ask and help their co-workers voluntarily in the integration and dissemination process of explicit knowledge through sorting, adding, combining, and categorizing related sales knowledge. In this process, a salesperson applies explicit knowledge so that new sales methods emerge. This aims to improve the sales knowledge that they have mastered.

By using examples of documents and sales data that have been neatly and systematically arranged, salespeople use them to preach and ask their co-workers to do the same. However, when they realized that not all team members could do it, they opened up and took the time to help their team members combine their sales documents. This intrinsic motivation has been proven to substantially influence performance (Bodla \& Naeem, 2014)(Bassous, 2014). Moreover, motivation based on religion will more significantly improve performance (Zahrah et al., 2016) because the intention is not only for worldly goals but has already reached the intention of seeking God's blessing.

H3: The stronger the voluntary asking and helping spirit in combining knowledge, the higher the selling performance. 
The fourth process in SECI is internalization, which adds explicit knowledge to each individual's tacit knowledge through facilitation skills, knowledge zones, or customer feedback reviews. Voluntary helping and asking others in the Internalization process is the spirit of individuals to help their colleagues add explicit knowledge to their respective tacit knowledge. If this spirit is applied to salespeople, then a salesman who is enthusiastic about asking his colleagues to internalize knowledge always propagates the importance of participating in new knowledge internalization activities in a knowledge zone. They convince their co-workers to use customer feedback to enrich their tacit knowledge about dealing with customers. If his co-workers feel unable to do so, then he voluntarily helps understand how to do internalization.

Individuals who have the spirit of voluntary asking helping on internalization are learners. They try to enrich their tacit knowledge because they believe that learning is lifelong, "from the swing to the grave". This activity of enriching tacit knowledge does not stop only for its own sake but is also followed by a spirit to encourage team members to do the same. If team members feel unable to achieve optimal selling performance, they sincerely help to overcome it. They did it so that the teammate would not be left behind. This activity can only be done by individuals with a high level of religiosity. Someone who has a high religious commitment does not expect a reward for what he did and tends to have high work awareness (Cardoș \& Mone, 2016). If knowledge internalization activities are applied in sales activities, new knowledge about managing customers will be able to be responded quickly so that sales targets increase.

H4: The stronger the voluntary asking and helping spirit in internalizing knowledge, the higher the selling performance.

\section{Empirical Model}

Based on a complete and in-depth literature review, the empirical research model can be presented in the figure below.

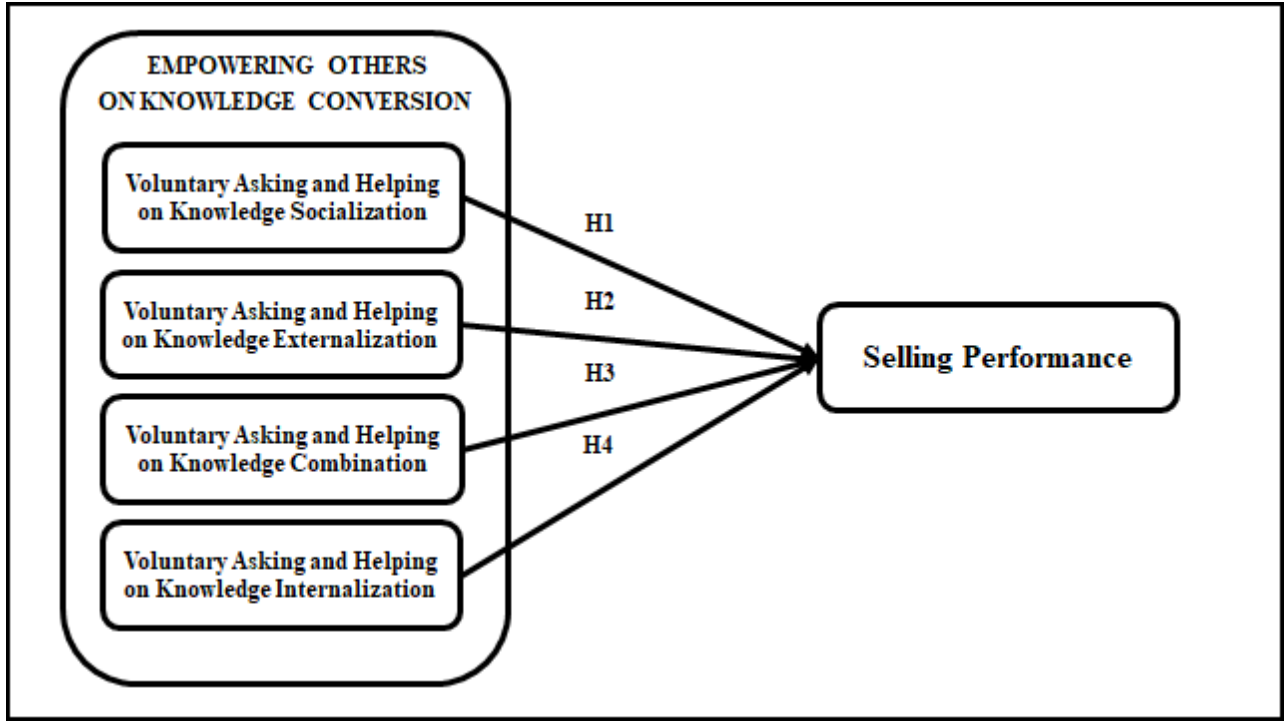

Figure 1: Empirical Research Model

\section{METHODS}




\section{Population, Sample and Data Collection}

Salespeople from 63 insurance companies with sharia principles in Indonesia registered with the Financial Services Authority in 2018 were selected as the population in this study. Because this study involves sales activities, choosing a salesman as the unit of analysis is a justifiable reason (Singh \& Venugopal, 2015). Respondents were taken from the ten-best performing Islamic insurance companies according to the Financial Services Authority in 2018. Snowball sampling was chosen as the sampling technique by selecting respondents using purposive sampling. The characteristics of the respondents included in the criteria are: (1) salesmen are members of a Sharia insurance sales team, and (2) have worked as salesmen for sharia insurance products for at least one year.

Two hundred fifty questionnaires were distributed directly to salespeople during the period from October 2019 to December 2019. Of the 250 questionnaires distributed, only 222 copies $(88.8 \%)$ were returned, and only 193 copies $(86.9 \%)$ were ready to be processed, while $29(13.1 \%)$ exemplars cannot be used because the data is incomplete. The question items in the questionnaire have gone through a rigorous process. Respondents consisted of $79 \%$ men and $21 \%$ women aged between 24 to 48 years. The education level of most $(63.2 \%)$ is undergraduate, $36.8 \%$ diploma. The working period is between 1 to 5 years, $72.4 \%, 6$ to 10 years $22.4 \%$. Salespeople are predominantly Muslim, as many as $93.1 \%$, and the rest are Hindus and Christians.

\section{Measurement}

Empowering others on knowledge conversion is defined as the spirit of salesmen in a sales team to do the best in the process of knowledge conversion and improve it continuously while asking and helping colleagues to be willing and able to convert knowledge (McClelland, 1987;Khan, Breitenecker and Schwarz, 2015;Yu et al., 2013, Nonaka, 1994) and Islamic values. Empowering others on knowledge conversion has 4 dimensions, namely: First, Voluntary Asking and Helping on Knowledge Socialization (VAHonKS) is defined as the spirit of salesmen to disseminate the best knowledge and continue to improve it while asking and helping colleagues in conducting knowledge dissemination related to sales knowledge as measured by 4 indicators. Second, Voluntary Asking and Helping on Knowledge Externalization (VAHonKE) is defined as the enthusiasm of salesmen to externalize the best knowledge and continue to improve it while asking and helping colleagues in externalizing knowledge related to sales knowledge as measured by 4 indicators. Third, Voluntary Asking and Helping on Knowledge Combination (VAHonKC) is defined as the spirit of the salesman to make the best combination of knowledge and continue to improve it while asking and helping colleagues in making a combination of knowledge related to sales knowledge as measured by 4 indicators. Fourth, Voluntary Asking and Helping on Knowledge Internalization (VAHonKE) is defined as the spirit of salesmen to internalize the best knowledge and continue to improve it while asking and helping colleagues in internalizing knowledge related to sales knowledge as measured by 4 indicators.

\section{Selling Performance}


Selling Performance (SP) is the achievement of a salesperson's sales work as measured by four indicators, namely: sales target, number of new customers, retaining customers, number of sales (Fernández-Sabiote \& Román, 2016);(Polo Peña et al., 2017).

\section{FINDING}

\section{Reliability and validity}

The results of data analysis showed that Cronbach Alpha $(\alpha)$ from all constructs ranged from 0.751 to 0.865 , showing good reliability. Whereas the p-value of each indicator which is less than 0.05 shows a very good indicator validity.

Table 1: Confirmatory Factor Analysis Results for the Measurement Model $^{\mathrm{a}}$

\begin{tabular}{|c|c|c|c|}
\hline & $\mathrm{R}$ & p-value & CA (ó) \\
\hline \multicolumn{4}{|l|}{$\begin{array}{l}\text { Voluntary Asking and Helping on Knowledge Socialization } \\
\text { (VAH on KS) }\end{array}$} \\
\hline - I am passionate about disseminating the best knowledge & $0.723 * *$ & 0.000 & 0.786 \\
\hline - I continuously improve the way I do knowledge dissemination & $0.659^{* *}$ & 0.000 & 0.752 \\
\hline - I sincerely ask my colleagues to disseminate knowledge & $0.664 * *$ & 0.000 & 0.766 \\
\hline $\begin{array}{l}\text { - I sincerely help my coworkers to be able to disseminate the best } \\
\text { knowledge. }\end{array}$ & $0.744 * *$ & 0.000 & 0.791 \\
\hline \multicolumn{4}{|l|}{ Voluntary Asking and Helping others on Knowledge } \\
\hline \multicolumn{4}{|l|}{ Externalization (VAH on KE) } \\
\hline - I am passionate about illustrating the best way of selling & $0.781^{* *}$ & 0.000 & 0.813 \\
\hline $\begin{array}{l}\text { - I continually improve the illustrations on how to make the best- } \\
\text { selling method }\end{array}$ & $0.668 * *$ & 0.000 & 0.843 \\
\hline - I sincerely ask my coworkers to illustrate the best-selling methods & $0.749 * *$ & 0.000 & 0.762 \\
\hline $\begin{array}{l}\text { - I sincerely help my coworkers to be able to illustrate the best-selling } \\
\text { methods }\end{array}$ & $0.707 * *$ & 0.000 & 0.744 \\
\hline \multicolumn{4}{|l|}{$\begin{array}{l}\text { Voluntary Asking and Helping on Knowledge Combination } \\
\text { (VAH on KC) }\end{array}$} \\
\hline $\begin{array}{l}\text { - I am intensely involved in the process of combining documents on } \\
\text { how to make the best-selling method }\end{array}$ & $0.678 * *$ & 0.000 & 0.834 \\
\hline $\begin{array}{l}\text { - I am constantly improving how to combine documents about how to } \\
\text { make the best-selling method }\end{array}$ & $0.655^{* *}$ & 0.000 & 0.859 \\
\hline $\begin{array}{l}\text { - I sincerely encourage my colleagues to be active in the process of } \\
\text { combining documents about how to make the best-selling method }\end{array}$ & $0.771^{* *}$ & 0.000 & 0.877 \\
\hline $\begin{array}{l}\text { - I sincerely help my coworkers to be able to combine documents about } \\
\text { how to make the best-selling method }\end{array}$ & $0.709^{* *}$ & 0.000 & 0.861 \\
\hline \multicolumn{4}{|l|}{$\begin{array}{l}\text { Voluntary Asking and Helping on Knowledge Internalization } \\
\text { (VAH on KI) }\end{array}$} \\
\hline $\begin{array}{l}\text { - I am passionate about internalizing new sales knowledge in my sales } \\
\text { activities }\end{array}$ & $0.780 * *$ & 0.000 & 0.792 \\
\hline - I continuously internalize new sales knowledge in my sales activities & $0.727 * *$ & 0.000 & 0.765 \\
\hline $\begin{array}{l}\text { - I sincerely ask my colleagues to internalize new sales knowledge in } \\
\text { their sales activities }\end{array}$ & $0.672 * *$ & 0.000 & 0.772 \\
\hline $\begin{array}{l}\text { - I sincerely ask colleagues to be able to internalize new sales } \\
\text { knowledge in their sales activities }\end{array}$ & $0.711^{* *}$ & 0.000 & 0.780 \\
\hline \multicolumn{4}{|l|}{ Selling Performance (SP) } \\
\hline - Able to achieve sales quantity targets as specified & $0.744 * *$ & 0.000 & 0.823 \\
\hline - Able to get the number of customers according to the target set & $0.738 * *$ & 0.000 & 0.807 \\
\hline - Able to retain existing customers. & $0.711^{* *}$ & 0.000 & 0.782 \\
\hline
\end{tabular}




\section{Hypothesis Testing Results}

The calculated $F$ value in the regression test results is 112.571 , with a $p$-value of 0.000 . This means that the regression model has good goodness of fit. The results of the normality assumption test using the K-S test showed a significance level of 0.068 . This figure shows that the residual value in the regression model is normally distributed. The Glesjer test results show a number above 0.05 . This shows that there are no symptoms of heteroscedasticity. The value of variance inflatoir factor (VIF) below 10 indicates that there is no multicollinearity.

The results of hypothesis testing on the regression model showed that the VAHonKS regression SP $(\beta=0.318$, p-value $<0.05)$; VAHonKE SP $(\beta=0.322$, p-value $<0.05)$, VAHonKC SP $(\beta=0.273$, $p$-value $<0.05)$ and VAHonKI SP $(\beta=0.248$, $p$-value $<0.05)$. Based on the results of these calculations, it can be stated that all hypotheses consisting of $\mathrm{H} 1, \mathrm{H} 2, \mathrm{H} 3$ and $\mathrm{H} 4$ are accepted.

Table 2: Parameter estimate for the path: Direct effects

\begin{tabular}{clllllll}
\hline Hypothesis & Regression & Beta & B & SE & CR & p-value & Results \\
\hline $\mathrm{H}_{1}$ & VAHonKS $\rightarrow$ SP & 0.318 & 0.352 & 0.062 & 2.557 & 0.000 & Accepted \\
$\mathrm{H}_{2}$ & VAHonKE $\rightarrow$ SP & 0.322 & 0.371 & 0.073 & 2.647 & 0.000 & Accepted \\
$\mathrm{H}_{3}$ & VAHonKC $\rightarrow$ SP & 0.273 & 0.291 & 0.078 & 2.804 & 0.002 & Accepted \\
$\mathrm{H}_{4}$ & VAHonKI $\rightarrow$ SP & 0.248 & 0.275 & 0.084 & 2.871 & 0.003 & Accepted \\
\hline Adj R2 = 0.314; $\mathrm{F}=112.571$, p-value $=0.000 ; \mathrm{K}-\mathrm{J} Z=0.79$, p-value $=0.068$ \\
Notes: VAHonKS=voluntary asking helping on knowledge socialization, VAHonKE=voluntary asking \\
helping on knowledge externalization, VAHonKC=voluntary asking and helping on knowledge combination, \\
VAHonKI=voluntary asking and helping on knowledge internalization, SP=selling performance \\
\hline
\end{tabular}

\section{DISCUSSION}

The importance of empowering others on knowledge conversion in improving the selling performance of sharia insurance salespeople has been proven in this study. Organizations that successfully implement knowledge creation more efficiently and productively will perform better (Nonaka et al., 1994);(Pathirage et al., 2007). The spirit of asking and helping co-workers to be willing and able to do knowledge conversion has proven to increase the number of customers and retain existing customers. Each salesperson with unique sales knowledge interacts with each other to create a new method of selling sharia insurance to achieve the sales target. The spirit to ask and help sales team members continue to do their best in converting their sales knowledge has proven to increase customer satisfaction. This happens because the congregation's spirit in a sales team can explore, accumulate, and disseminate tacit knowledge about sales activities inherent in each salesperson. This conclusion is supported by the results of a study conducted by (Lee \& Choi, 2003)that organizations that carry out the knowledge creation process well are better able to combine knowledge in different ways and provide value to consumers.

Hypothesis 1 test results have proven the ability of voluntary asking and helping on knowledge socialization in improving the selling performance of sharia insurance salesmen. The socialization process as the first stage of knowledge conversion can be interpreted as a part of knowledge sharing. Sharing, in this case, is not only about sharing information but also the process of wanting to know how and why (Wamitu, 2015). Hence, if a salesman is 
eager to socialize knowledge about how to achieve the best sales activity, at that time, he will be involved in a discussion forum so that take and give information occurs because basically, knowledge sharing cannot be done individually. If salesmen socialize how to work professionally, reciprocally, they will receive feedback from colleagues based on their unique experiences. The socialization process of salesperson by giving awareness to his coworkers to work professionally can be a mirror for himself to behave similarly. Furthermore, it enriches his sales knowledge so that he is better able to achieve sales targets. Various socialization processes such as brainstorming, informal meetings, dialogues, observations, and learning groups that discuss how to use resources efficiently, make salesmen able to satisfy customers. Identical feeling because they are in the same team encourage them to offer help if there are coworkers who are unable to disseminate knowledge. He did the assistance continuously until finally his colleague was able to tell in detail about his experience in dealing with customers. The more complete information will enable it to achieve sales targets.

Hypothesis 2 test results have also proven the role of voluntary asking and helping on knowledge externalization in improving selling performance. In this process, employees willingly make the best illustrations of ways to satisfy customers so that tacit knowledge hidden in their minds is more easily communicated and can be understood by colleagues (King, 2009). Thus, when tacit is transformed into explicit, it will be easier to understand and share with others and become the basis for the emergence of new knowledge (Janhonen \& Johanson, 2011). Therefore, sales documents are neatly organized so that they can be studied repeatedly and can be shared with colleagues, without worrying about reducing their income. Religious values make him realize that fortune is in the hands of God. Realizing that not all of his colleagues are able to illustrate tacit knowledge, salesmen are willing to offer a help to create good documents. His coworkers are reminded that illustrating tacit knowledge is useful for providing solutions to similar sales problems, because basically, serving a variety of customers is repetitive. Finally, through this knowledge sharing, the salesman will get feedback from his colleagues so that his knowledge illustrations are getting better and more complete so that he is able to increase his selling performance.

The combination of knowledge as the third stage of the knowledge conversion process has also been proven to be able to increase selling performance. At this stage, each sales team member voluntarily exchanges the best documents and is communicated to his teammate with good body language and spoken language. They are also involved in classifying customer characters and how to deal with them. In the process of sorting, adding, and combining, each salesman gets new knowledge about the customer so that he understands some of the main characters of the customer. This new knowledge can be used as a preparation for applying new ways that are better suited to customer demands so that their sales targets can be met. The enthusiasm of salesmen to ask colleagues to do a combination of knowledge increases the amount of knowledge combined so that more alternative sales methods can be used to understand the desires of diverse customers so that the number of customers will increase.

Hypothesis 4 test results have proven the important role of voluntary asking and helping on knowledge internalization in increasing the number of new customers. The more enthusiastic the salesman is in updating their knowledge, expanding and transforming it into their own tacit knowledge so as to further enable their ability to satisfy customers. This enthusiasm was transmitted to his coworkers to do the same with him. Salesmen who are increasingly eager to 
provide the best for the sales team, will be excited in asking colleagues to be able to internalize the knowledge that he mastered and he believes to be the most effective way to satisfy customers. He is ready to help whenever his coworkers need it, to ensure that his best sales knowledge has been able to be internalized by his coworkers to update his sales methods in order to retain customers. The more often a salesman asks and helps his coworkers to internalize the best sales knowledge, at that time, the salesman simultaneously reminds himself to do the same. The more knowledge that is internalized, it will form a new tacit knowledge about how to serve customers so that the selling performance will increase.

\section{CONCLUSION}

This study still has some limitations, where these limitations are expected to be an opportunity for further researchers. First, this study used cross-sectional research so that the research design cannot ascertain the causal relationship specified in the hypothesis. Future research is recommended using the longitudinal method. Second, this research only focused on Islamic insurance with an Indonesian cultural background, so that future research can compare by taking samples of Non-Sharia Insurance Salespeople and involving other cultural factors to validate results with a broader spectrum.

\section{REFERENCES}

Bassous, M. (2014). What are the Factors that Affect Worker Motivation in Faith-Based Nonprofit Organizations? Voluntas, 26(1), 355-381. https://doi.org/10.1007/s11266013-9420-3

Behaviors, K., Murtaza, G., \& Abbas, M. (2014). Impact of Islamic Work Ethics on Organizational Citizenship. 106-112. https://doi.org/10.1007/s10551-014-2396-0

Bodla, M. A., \& Naeem, B. (2014). Creativity as Mediator for Intrinsic Motivation and Sales Performance. Creativity Research Journal, 26(4), 468-473. https://doi.org/10.1080/10400419.2014.961783

Calisir, F., Altin Gumussoy, C., \& Guzelsoy, E. (2013). Impacts of learning orientation on product innovation performance. The Learning Organization, 20(3), 176-194. https://doi.org/10.1108/09696471311328442

Cardoș, R. A. I., \& Mone, I. S. (2016). Religiousness, Spirituality And Work Values: A Step Forward For Work-Life Balance? Journal of Evidence-Based Psychotherapies, 16(1), $67-77$.

Chen, Y. H., Lin, T. P., \& Yen, D. C. (2014). How to facilitate inter-organizational knowledge sharing: The impact of trust. Information and Management, 51(5), 568-578. https://doi.org/10.1016/j.im.2014.03.007

Elias, A. A., \& Davis, D. (2018). Analysing public sector continuous improvement: a systems approach. International Journal of Public Sector Management, 31(1), 2-13. https://doi.org/10.1108/IJPSM-08-2016-0135

Fernández-Sabiote, E., \& Román, S. (2016). The multichannel customer's service experience: building satisfaction and trust. Service Business, 10(2), 423-445. https://doi.org/10.1007/s11628-015-0276-z

Göksel, A., \& Aydıntan, B. (2017). How can tacit knowledge be shared more in 
organizations? A multidimensional approach to the role of social capital and locus of control. Knowledge Management Research \& Practice, 15(1), 34-44. https://doi.org/10.1057/kmrp.2015.22

Janhonen, M., \& Johanson, J. (2011). Role of knowledge conversion and social networks in team performance. International Journal of Information Management, 31, 217-219. https://doi.org/10.1016/j.ijinfomgt.2010.06.007

Karakas, F. (2010). Spirituality and Performance in Organizations: A Literature Review. Journal of Business Ethics, 94, 89-106. https://doi.org/10.1007/s10551-009-0251-5

Khan, M. S., Breitenecker, R. J., \& Schwarz, E. J. (2015). Adding fuel to the fire: Need for achievement diversity and relationship conflict in entrepreneurial teams. Management Decision, 53(1), 75-99. https://doi.org/10.1108/MD-02-2014-0066

Khodakarami, F., \& Chan, Y. E. (2014). Exploring the role of customer relationship management (CRM) systems in customer knowledge creation. Information and Management, 51(1), 27-42. https://doi.org/10.1016/j.im.2013.09.001

Lawson, B., Petersen, K. J., Cousins, P. D., \& Handfield, R. B. (2009). Knowledge sharing in interorganizational product development teams: The effect of formal and informal socialization mechanisms. Journal of Product Innovation Management, 26(2), 156-172. https://doi.org/10.1111/j.1540-5885.2009.00343.x

Lee, H., \& Choi, B. (2003). Knowledge Management Enablers, Processes, and Organizational Performance: An Integrative View and Empirical Examination. I, 179228.

Mosala-, N. N., Hoskins, R. G., Africa, S., \& Mosala-bryant, N. (2016). Motivational theory and knowledge sharing in the public service. Sourth African Journal of Information Management, 1-10.

Nonaka, I., Byosiere, P., \& Borucki, C. C. (1994). Organizational Knowledge Creation Theory: A First Comprehensive Test. International Business Review, 3(4), 337-351.

Nonaka, I., \& von Krogh, G. (2009). Perspective-Tacit Knowledge and Knowledge Conversion: Controversy and Advancement in Organizational Knowledge Creation Theory. Organization Science, 20(3), 635-652. https://doi.org/10.1287/orsc.1080.0412

Olowookere, E. I., \& Adekeye, O. A. (2016). Relationship between Religiosity and Citizenship Behaviours in Organizations: Empirical Evidence from Selected Organisations in Lagos State. Mediterranean Journal of Social Science, 7(4), 475-484. https://doi.org/10.5901/mjss.2016.v7n4p

Pathirage, C. P., Amaratunga, D. G., \& Haigh, R. P. (2007). Tacit knowledge and organisational performance: construction industry perspective. Journal of Knowledge Management, 11(1), 115-126. https://doi.org/10.1108/13673270710728277

Pfeffer, J., \& Veiga, J. F. (2009). first Putting people for organizational success *. The Academy of Management Executive, 13(2), 37-48.

Polley, D., \& Ribbens, B. (1998). Sustaining self-managed teams: A process approach to team wellness. Team Performance Management: An International Journal, 4(1), 3-21. https://doi.org/10.1108/13527599810212087

Polo Peña, A. I., Frías Jamilena, D. M., \& Rodríguez Molina, M. Á. (2017). The effects of perceived value on loyalty: the moderating effect of market orientation adoption. Service Business, 11(1), 93-116. https://doi.org/10.1007/s11628-016-0303-8 
Rosopa, P. J., Schroeder, a N., \& Hulett, a L. (2013). Helping yourself by helping others: Examining personality perceptions. Journal of Managerial Psychology, 28(2), 147-163. https://doi.org/10.1108/02683941311300676

Sabherwal, R., \& Becerra-Fernandez, I. (2003). An Empirical Study of the Effect of Knowledge Management Processes at Individual, Group, and Organizational Levels. Decision Sciences, 34(2), 225-260. https://doi.org/10.1111/1540-5915.02329

Singh, R., \& Venugopal, P. (2015). The impact of salesperson customer orientation on sales performance via mediating mechanism. Journal of Business and Industrial Marketing, 30(5), 594-607. https://doi.org/10.1108/JBIM-08-2012-0141

Swift, M., Balkin, D. B., \& Matusik, S. F. (2010). Goal orientations and the motivation to share knowledge. Journal of Knowledge Management, 14(3), 378-393. https://doi.org/10.1108/13673271011050111

Wamitu, S. N. (2015). Tacit Knowledge Sharing in Public Sector Departments in Kenya. Open Journal of Business and Management, Januari(3), 109-118.

$\mathrm{Wu}$, S. (2007). The influence of personal character on information communication and activity effect. Marketing Intelligence \& Planning, 25, 746-771. https://doi.org/10.1108/02634500710834205

Yen, Y. X., Wang, E. S. T., \& Horng, D. J. (2011). Suppliers' willingness of customization, effective communication, and trust: A study of switching cost antecedents. Journal of Business and Industrial Marketing, 26(4), 250-259. https://doi.org/10.1108/08858621111126992

Yu, Y., Hao, J. X., Dong, X. Y., \& Khalifa, M. (2013). A multilevel model for effects of social capital and knowledge sharing in knowledge-intensive work teams. International Journal of Information Management, 33(5), 780-790. https://doi.org/10.1016/j.ijinfomgt.2013.05.005

Zahrah, N., Norasyikin, S., Hamid, A., Huda, S., \& Rani, A. (2016). Enhancing Job Performance through Islamic Religiosity and Islamic Work Ethics. International Review of Management and Marketing, 6(S7), 195-198. 